\title{
Applying Sustainability and Ethics in Forest Management and Community Livelihoods: A Case Study from Arabuko Sokoke Forest, Kenya
}

\author{
Musingo T. E. Mbuvi1 ${ }^{*}$, Leila Ndalilo1, Aden Hussein ${ }^{2}$ \\ ${ }^{1}$ Kenya Forestry Research Institute, Coast Eco Region Research Programme, Malindi, Kenya \\ ${ }^{2}$ Manager Kipepeo Project, National Museums of Kenya, Gede, Kenya \\ Email: *mtembuvi@gmail.com, ^mtembuvi@hotmail.com, husseinaden52@gmail.com
}

How to cite this paper: Mbuvi, M. T. E., Ndalilo, L., \& Hussein, A. (2018). Applying Sustainability and Ethics in Forest Management and Community Livelihoods: A Case Study from Arabuko Sokoke Forest, Kenya. Open Journal of Forestry, 8, 532-552. https://doi.org/10.4236/ojf.2018.84033

Received: April 10, 2018

Accepted: October 20, 2018

Published: October 23, 2018

Copyright $\odot 2018$ by authors and Scientific Research Publishing Inc. This work is licensed under the Creative Commons Attribution International License (CC BY 4.0).

http://creativecommons.org/licenses/by/4.0/

\begin{abstract}
Efforts to manage forests continue to be enhanced equally as emergence of investments in community livelihoods whose benefits are inequitable. Literature review, focus group discussion and key informant interviews showed that Arabuko Sokoke Forest has been managed under different management regimes; stakeholders have increased from singular to multiple with each stakeholder's interests hinged on different conservation theories and ethical principles, despite that well-meaning facilitation, laws and policies, unsustainable and un-ethical scenarios abound. Extreme scenarios of a poor mother being denied firewood for lighting, warming and cooking food in order to conserve biodiversity. These are both right and wrong, a fluidity requiring situation specific sustainability and ethical justification. A discourse guided by the sustainable development goals provides a mechanism for moderating the diverse interests and helps bring harmony and synergies among all stakeholders for the common good without compromising the ecological functions of the forests thus ensuring sustainability.
\end{abstract}

\section{Keywords}

Forest, Equitable, Livelihoods, Sustainability and Ethics

\section{Introduction}

Forestry management in Kenya formally started in late 1890s' with the first legislation being enacted in 1891 and the first Chief Conservator of Forest being posted in 1902 (Logie \& Jones, 1968). It was after a century, in 1997, that the country initiated a process to change the century old singular command and 
control system in forest management, through piloting of Participatory Forest Management (PFM). It has been subsequently institutionalized as an alternative national forest management approach. Participatory Forest Management has been defined as a forest management approach, which deliberately involves the Forest Adjacent Communities (FAC) and other stakeholders in sustainable management of forests within a framework that contributes to community's livelihoods (Kenya Forest Service-KFS, 2015a).

The PFM pilot was done in Arabuko Sokoke Forest Reserve (ASFR) which is an indigenous coastal forest (Mbuvi \& Ayiemba, 2005). The changes in forest management approach were done to align forest management in Kenya with the requirement for protected areas to be equitably governed and managed as per the Convention on Biological Diversity's (CBD, 2010) goal 2.1 that calls for the promotion of "equity and benefit sharing" and goal 2.2 on enhancing "involvement of indigenous and local communities and relevant stakeholders", an initiative also in line with Aichi Biodiversity Target 11, which required that protected areas should be "effectively and equitably managed" (Schreckernberg et al., 2016: p. 1).

The forestry sector in Kenya faced a national outcry over unprecedented degradation in 1980s' (Wass, 1995; Republic of Kenya RoK, 2009a). A scenario similar to observations by Manning et al. (1999) that the current development paradigm of individual maximizing their material is leading to conversion of forest to other land uses and may lead to catastrophic consequences to human wellbeing. This thinking calls for sustainable forest management for the inherent value of life therein.

This school of thought requires that ethical considerations be internalized in the management of forests. The forest ethics would operate at all levels from the community to the global citizen where a farmer collecting firewood for cooking for his family has to do it well aware of the effect it has on the habitat for the ASFR endemic birds which attract national and international researchers, citizens and development partners to learn and have immense biodiversity value.

This scenario brings up conflicts, realizing that the households requires firewood in order to eat while the bird relies on the insects habiting in the same wood a household requires for survival. This call for limiting of the amount of firewood collected through setting quotas and delineation of firewood collection zones through a management planning process (Forest Department, 2002; KFS, 2015b). Are these decisions fair? remains a key question as they bring up the issue of: the rich and the poor; the powerful and weak; well connected (more partners) and lone-rangers situations where the latter have ability to seek alternatives, and push for their positions and interests, hence pushing for the poor to forego use of firewood as a source of energy even when their well-being status can hardly allow. In ASFR the community rely heavily on firewood as a source of energy (Mbuvi et al., 2007; Ndalilo et al., 2017). This calls for pressing need to save the collective good (Mbuvi et al., 2007; Matiku et al., 2013) from the whim of individuals who desperately require alternatives. 


\section{The Scenario in Arabuko Sokoke Forest Reserve}

The review is premised on analysis of scenarios that are operating in several forests in Kenya where communities have been participating in forest management with defined benefits by law, though the law may not be providing adequate opportunities. The challenge is more on the process (implementation). Arabuko Sokoke forest reserve was chosen for review but also quotes scenarios from other select forest in Kenya. ASFR was given special attention because it draws local, national and global interest. It is the forest that had the first forest management plan approved by the Chief Conservator of Forests (Forest Department, 2002). The forest has also gone through all the phases of governance; community managed, government managed and PFM. The forest has been receiving adequate funding (Appendix I) from government, national and global development partners supported by very enthusiastic community. This has ensured that the forest is exposed to best global practices and experiences through interaction with re-known conservationists and development experts. After PFM pilot (Mbuvi \& Ayiemba, 2005; Matiku et al., 2013), ASFR is now focusing on governance, livelihoods, maximizing on returns from Income generating Activity (IGA) and leveraging on the partnerships to support organizational stability at the forest level. This calls for collective ethics as different partners seek to maximise on both conservation and livelihood gains (Manning et al., 1999).

\subsection{Description and Management of Arabuko Sokoke Forest Reserve}

The Arabuko-Sokoke Forest Reserve (ASFR) is a lowland dry forest in the Coastal region of Kenya, starting at sea level with the mangroves at the Mida Creek. It is located in Kilifi County about $110 \mathrm{~km}$ North of Mombasa (Figure 1) at a latitude of $3^{\circ} 20^{\prime} \mathrm{S}$ and a longitude of $39^{\circ} 50^{\prime} \mathrm{E}$ (Forest Department, 2002). The forest experiences bi-modal rainfall pattern with short rain season occurring between November and December and the long rains falling between April and June. The average annual rainfall fluctuates from the East part to the West part of the forest ranging from $900 \mathrm{~mm}$ in the Northwest to $1100 \mathrm{~mm}$ in the East. The forest is located in a humid and hot climate zone and its temperature averages about $29^{\circ} \mathrm{C}$ (Muriithi \& Kenyon, 2002).

The Arabuko-Sokoke Forest Reserve was declared a crown forest in 1932 and gazetted in 1943, later in 1968 more forest area (Kararacha extension) was added to it (Forest Department, 2002). The gazettement was meant to address the conservationists believe that we have an ethical obligation to act as stewards for the other species with which we share this planet (Robinson, 2011). Arabuko-Sokoke Forest Reserve is the largest remnant of the mosaic of forests that covered the East Coast of Africa from Somalia to Mozambique (Matiku et al., 2013). The forest has a total area of 420 square kilometres and plays an important role in the conservation of biodiversity that is endemic to the ecosystem. The forest is 


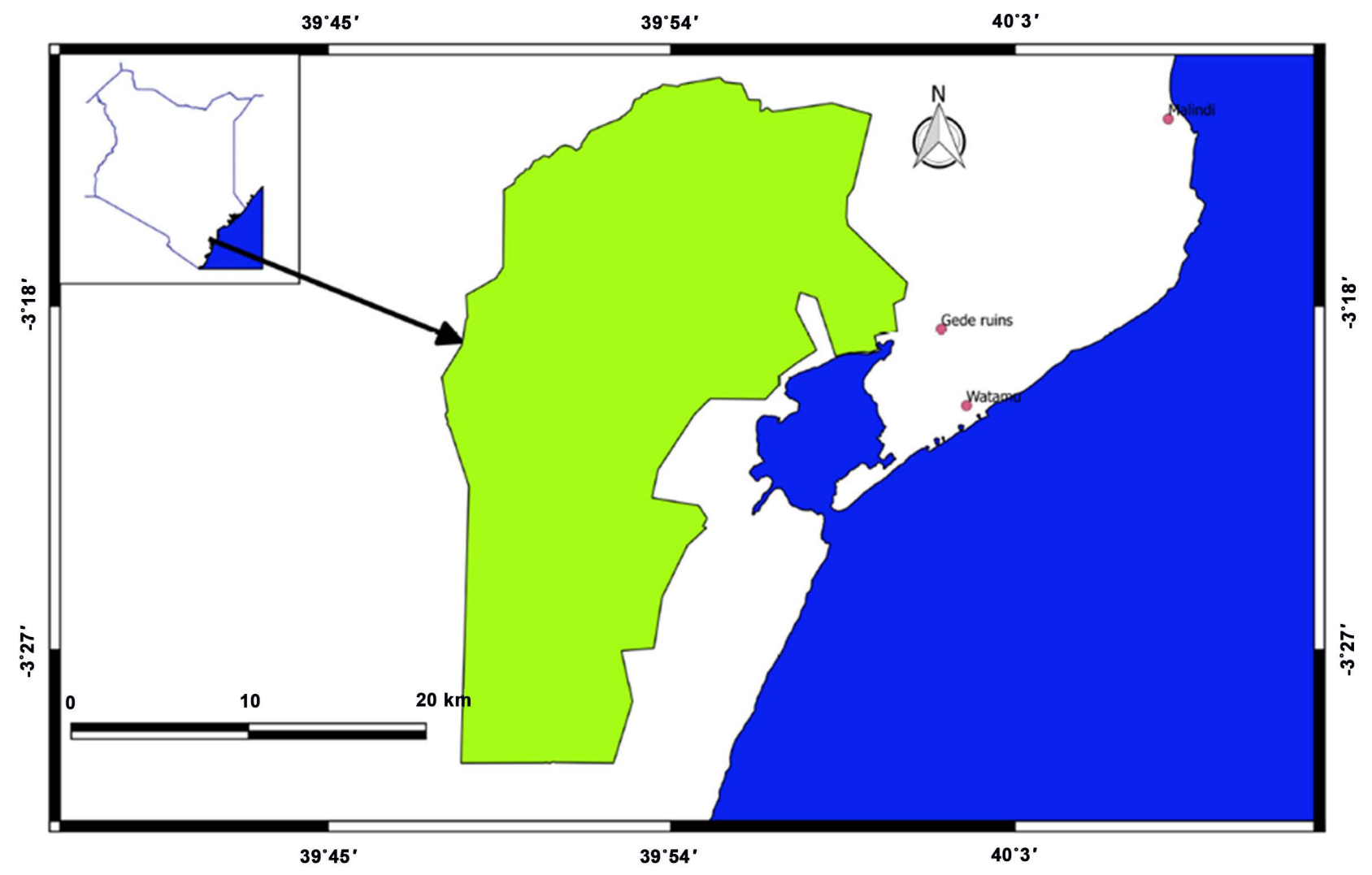

Figure 1. Arabuko Sokoke forest.

managed by three forest stations: Gede; Sokoke and Jilore each manned by Forest Manager assisted by armed forest rangers actively supported by communities organized through station based Community Forest Associations (CFAs).

The Arabuko-Sokoke Forest Reserve is an indigenous forest whose direct use for products like timber and poles is hardly possible. This is because the draft forest policy 2015, states that indigenous forests will be put under efficient and sustainable multipurpose management, which combines biodiversity conservation and water-catchment functions together with the production of tangible benefits for forest adjacent communities (Ministry of Environment, Water and Natural Resources MEWNR, 2015). This scenario poses a challenge to the adjacent communities especially the poor who view the forest as a means to escape from poverty and perceive the introduction of PFM as the start of that process.

The ASFR is managed under national and global laws and policies and has involved several stakeholders with diverse interests (Forest Department, 2002). The different stakeholders are guided by specific laws, policies and principles and include governmental, non-governmental organizations, and local communities. Each of the stakeholders involved in the management of the forest expects to maximize their benefits. The common objectives in the management of the forest are what bind the different stakeholders to work together. The different stakeholders have different claims to the rights to manage and access the forest resources and have varying degrees of importance and influence. The existing 
laws and policies provide the rules and regulate the actions and power sharing mechanisms for the different stakeholders.

Therefore, the conservation of ASFR has been complex as noted by Gore et al., (2011) that the conservation policy choices can be complicated by stakeholder debate over the value of an individual animal's life, humans' role in nature, or the effectiveness of conservation actions. This is complicated by the different ethical principles which each stakeholders use to guide their actions and claims. This forms the basis of our discussion for this paper.

\section{Theoretical Framework}

Man and forests have coexisted over centuries and there have been several movements all over the world for inclusivity of human being in the management of forests for supply of goods and services (Guha, 1989; FAO, 1999; Gibson et al., 2000). Normative ethical theory guided in the understanding of different concepts on ethics and sustainable forest management. Normative theory defines what is right or wrong in the society and also helps the society to come up with sanctions for wrong doing so that those who deviate from the norm can be corrected. By defining what is right or wrong the society makes adjustments and the behaviour of different persons are regulated for the common good of all. According to (Kant, 1968), human behaviour is controlled by what they consider as rational and this rationality helps them act rationally and expect the same from others. In the context of forest management this therefore means that humans interact with the forest through actions that are rationally defined to ensure that their actions and those of others are such that they don't affect the forests negatively and that as they benefit from forest goods and services, they don't affect each other and also the forest hence sustainability of the forests. The different actors in forests management also operate within the confines of culturally defined norms and the existing laws to remain relevant and acceptable to the society through the development of management agreements (KFS, 2015a) and management plans which are negotiated between the community forest associations and the Kenya Forest Service (RoK, 2009a; KFS, 2015b).

\section{Methodology}

The study adopted a case study approach in which Arabuko Sokoke forest was comprehensively analysed as case study. Detailed literature review was conducted, 32 key informant interviews conducted, 8 focus group discussion conducted and expert opinions documented through key informant interviews. Through the different methods we gathered information on the history of the forests and forest management practices. The different themes were synthesized and formed the basis for the full discussion of the paper.

Detailed literature review was carried out on research carried out in Arabuko Sokoke forest from 1997 when PFM was piloted in the forest to 2017 (Oyugi et al., 2007; Forest Department, 2002; Muriithi \& Kenyon, 2002; Mbuvi \& 
Ayiemba, 2005; Mbuvi et al., 2007; RoK, 2009a; RoK, 2009b; RoK, 2009c; RoK, 2010; RoK 2016a; Mbuvi et al., 2015; Ndalilo et al., 2017), to form the basis and draw parallels for the discussion on development and ethical issues affecting the forest. Experiences were also drawn from other parts of the world on how ethical issues have evolved and how they affect the management of forest in different parts of the world.

A total of 8 focus group discussion were conducted for in-depth analysis of the different issues that emerged during the individual interviews. Purposive sampling was used to select the respondents; two focus group discussions were held in each of the three forest blocks-Gede, Jilore and Sokoke, one with members of the CFA Management committees and the other with representatives of forest user groups. Each FGD comprised 10 people who were engaged in the discussions to explore the relevant issues in more details. The main issues probed included community involvement in decision making, resource utilization trends, access, benefit sharing and equity mechanisms, and compliance to legal and policy framework.

Key Informant interviews were conducted with persons who were privy to information relevant to the study. Staff from Kenya Forest Service (KFS), Kenya Forestry Research Institute (KEFRI), Kenya Wildlife Service (KWS), Nature Kenya, Arocha Kenya, and National Museums of Kenya (NMK) were interviewed using interview schedules to capture their opinions and experiences on historical changes in forest management, resource use, access and utilization trends, policy and legal issues governing forest resource use and management and ethical issues affecting sustainable management of forests. Retired staff of these organizations were also interviewed to get the historical perspectives on ethical issues as they evolved. Leaders of community groups and forest product licensees were also interviewed with retired officials acting as key informants. A total of 32 key informants were interviewed.

\section{Results and Discussion}

\subsection{Environmental Concerns in Arabuko Sokoke Forest Reserve}

Arabuko Sokoke forest reserve is ranked second in Africa and fifty globally in biodiversity richness (Forest Department, 2002). It is the largest remnant of what was originally an extensive strip of dry coastal forest that extended from Southern Somalia in the horn of Africa to the Eastern Cape in the south (Forest Department, 2002; Oyugi et al., 2007). The forest is however threatened by habitat degradation resulting from economic development, poor forest governance and high levels of poverty among forest adjacent communities (Ndalilo et al., 2017).

Tourism development and urbanization is increasingly posing a threat to conservation of the forest with the latest development being the desire by a few stakeholders to create a forest park. An opportunity that is legally possible (RoK, 2016a). It is likely to get support because it promises better conservation, ecotourism development, employment creation and better livelihoods for communi- 
ties. Although the local community perceive the forest as a source of fuelwood and other subsistence uses (Matiku et al., 2013; Mbuvi et al., 2007). Conservationists on the other hand see livelihoods as a threat to the forest further marginalizing the poor and vulnerable members of the community whose livelihoods are almost entirely dependent on the forest. The high levels of poverty that encourage poaching of forest products (Mbuvi et al., 2007), coupled with lack of alternative livelihood activities poses a major challenge to the conservation and management of ASFR.

The other major potential threat to ASFR remains mining in the forest and adjacent areas recognizing that prospecting has been done with promising results for Titanium, oil and gas, while compensation for CFAs may not be guaranteed. The high interest generated by the anticipated high returns and the need for industrialization by the government and economic growth may weigh negatively on continued conservation of the forest, hence impacting negatively on the role of ASFR in biodiversity conservation and socio-economic development. The forest provides fresh water re-charge that is necessary for continued growth of the Mida creek mangrove ecosystem which supports fisheries for food security and economic development. Mida Creek also has the oldest mangrove board walk in Kenya with a very active eco-tourism project which contributes significantly to local livelihoods and conservation of mangrove ecosystem as guided by a Participatory Forest Management Plan (PFMP). The conservation of ASF thus contributes to SDG 14 on conservation and sustainable use of oceans, seas and marine resources for sustainable development. It also contributes directly to SDG 15: Protect, restore and promote sustainable use of terrestrial Ecosystems, sustainably manage Forests, combat desertification, and halt and reverse land degradation and biodiversity loss.

\subsection{Ethical Issues in the Management of Arabuko Sokoke Forest from a Historical Development Perspective}

Forest ethics operate at many levels-local, national or international, and ethical conflicts in forestry are common place because multiple different aspirations regarding different forest products and services exist over extensive geographical areas and timeframes (Macqueen, 2004). For example, both local farmers and international climatologist have legitimate grounds for wanting or opposing forest clearance, but their conflict arises because forests generate aspirations at different levels (Manning et al., 1999). The local farmers control over his future depends firmly on clearing a particular local patch of forest. The international climatologist is concerned about long term changes at the global level (Manning et al., 1999). Both might share the same forest ethic, but the level at which their aspiration is based differs as noted by Manning et al. (1999). Ethics as was noted by Horn (2013) refers to habits of thought and behaviour that emphatically take others interests into account in order to achieve greater good.

The current development paradigm focused on maximizing individual material wealth is sweeping aside natural forests (Manning et al., 1999). In ASFR, 
benefits disproportionately accrue to the well off in society (Mbuvi \& Ayiemba, 2005; Mbuvi et al., 2015). Such forests simply cannot compete in terms of revenue generated per unit area, with land use alternatives yet continued conversion of natural forests to other land uses may have catastrophic consequences for human well-being. Currently, the main ethical issues affecting forest management include; the mismatch between the ethical driving forces affecting forests such as maximising individual wealth and proposed solutions which appeal to broader notions of human well-being; adequate and balanced representation from those suffering the consequences of forest loss rarely matches the power of those perpetrating it; individual or sovereign self-interests impede any attempt to develop a higher collective vision to the benefit of all; and short term restrictions of behaviour are preferred to long term changes in behaviour (Manning et al., 1999).

ASFR was gazetted as a forest reserve in 1943 during which commercial and subsistence utilization of the forest was allowed for timber, poles, firewood, carving wood and sand harvesting for glass making. Local communities were also allowed free access to defined products legally through special rules for ASFR. This was fair then as the resource was adequate, the community demands were low, population was very low and demand for forest products was negligible as to cause forest degradation.

With the ever increasing population and high demand for forest products and agricultural land adjacent to the forest, the main ethical concerns in ASFR are; 1) was it right to reduce the community forest products provisions when the forest products were declining? 2) Is there an equitable benefit sharing mechanism with regard to local communities access to forest resources; and 3) Is it right to protect elephants while denying local communities the opportunity to protect their crops and exploit a valuable natural resource? These kind of ethical dilemmas are not easily resolvable.

In ASFR, conservation efforts aspired to achieve a win-win situation like with the erection of an electric fence to confine elephants inside the forest as a means to protect crops. In some instances though, conservation has impacted on the communities' access to forest resources, retention of their traditional rights, or usufruct rights. The communities have however been provided with alternatives which are limited as they are accessed through group membership (KFS, 2015a; Mbuvi et al., 2015) further alienating the majority. Subsequent legislations such as the Forest Conservation and Management Act 2016 though have allowed community access to forest resources including subsistence fuelwood collection from the forest and non-consumptive uses like eco-tourism and butterfly farming, other commercial access is limited by legislative prescription and technical requirements like plans and numerous permits for extraction and business requirements (RoK, 2009c; RoK, 2010; RoK, 2016a; RoK, 2016b). Local communities consider this practise un-ethical and have proposed a scenario that provides for fair access to forest products. This is in line with Robinson (2011) who argues that conservation organizations are expected to be responsive to a number 
of ethical obligations beyond that of the: conservation of biodiversity; the reduction of poverty; imperative of social justice and cultural integrity and the improvement in human livelihoods. This should ensure that people access to resource is fair, there are no privileged groups of people over others, and some species are not conserved at a cost to others.

Previous studies conducted in ASFR (Mbuvi et al., 2007; Ndalilo et al., 2017) established that informal access to forest products particularly timber and poles give the FAC the highest benefit; although the newly initiated donor funded IGAs are substantially benefiting households (Mbuvi, \& Ayiemba, 2005; Matiku et al., 2013). The communities adjacent to ASFR have been alienated from access to forest resources and decision making, compensation and damage to crops. These bring the ethical questions of: What is the highest benefit the communities are accessing from the forest, how does the law support it and how sustainable is the benefit? Who bear the highest responsibility? Who should be the first beneficiary? Who takes care of the global good?

\subsection{Economic Development and Implication on Ethics and Sustainability}

The forest is witnessing increased urbanization in Kilifi, Watamu and Malindi and the small adjacent Gede shopping centre whose residents shall continuously require forests for recreation in the midst of a poor forest adjacent community viewing the forest as a means to escape from poverty and perceive their participation in forest management as the beginning of that shift (Mbuvi \& Ayiemba, 2005).

The ASFR is a tourist destination, and tourism among other products and services generates revenue to the government from payment of fees by both local and international forest users as outlined in Table 1.

Over the years, there has been a great push by local communities and civil society organizations to share the accruing revenues equitably but the local communities have always ended up holding the short end of the stick. This scenario is changing as the Forest Conservation and Management Act 2016 has explicitly provided for opportunities for accessing of both subsistence and commercial products under various forest management scenarios from joint management, leases and concessions and increasing of tree cover as incentives and benefits. Communities are increasingly feeling alienated from the forest benefits despite; the Kenya Constitution 2010 requirements (RoK, 2010) and community active role in conserving the forest. This has resulting to an ethical conflict, with the net effect being the illegal harvesting of forest products as FAC lack incentives to effectively engage in forest conservation.

According to Ndalilo et al. (2017), poverty results in heavy domestic demands, especially for firewood, building materials, and illegal activities such as poaching of animals and harvesting of poles which are sold in the surrounding urban areas such as Malindi, Kilifi and Mombasa. Such activities endanger forest resources which support local communities leading to a vicious cycle of forest degradation 
Table 1. Revenue* trend for ASFR.

\begin{tabular}{|c|c|c|c|c|c|c|c|c|c|c|c|c|}
\hline Year/station & 2005 & 2006 & 2007 & 2008 & 2009 & 2010 & 2011 & 2012 & 2013 & 2014 & 2015 & 2016 \\
\hline $\begin{array}{l}\text { Gede and } \\
\text { Jilore }\end{array}$ & 19,396 & 428,773 & 310,541 & 266,351 & 479,416 & $2,438,666$ & $2,299,557$ & $1,954,801$ & $1,475,320$ & $1,870,745$ & $2,323,456$ & $2,134,897$ \\
\hline $\begin{array}{l}\text { Sokoke } \\
\text { stations }\end{array}$ & 0 & 0 & 0 & 78,000 & 76,700 & 101,100 & 30,800 & 215,700 & 228,900 & 301,500 & 211,700 & 295,600 \\
\hline Total & 19,396 & 428,773 & 310,541 & 344,351 & 556,116 & $2,539,766$ & $2,430,357$ & $2,170,501$ & $1,704,220$ & $2,172,245$ & $2,535,156$ & $2,430,497$ \\
\hline
\end{tabular}

Source: KFS Records; ${ }^{*}$ in Kenya shillings: 1 USD $=100$ Kenya shillings.

and poverty. This conforms to Brundtland report, which stated that: "Those who are poor and hungry will often destroy their immediate environment in order to survive...." (Schreckernberg et al., 2016).

Community access to resources has been regulated in ASFR (Forest Department, 2002) which is an indigenous forest where direct exploitation is not allowed (RoK, 2016a). Access to resources by communities and other stakeholders has been mitigated through compensation, substitution and creation of alternatives. The alternative IGAs include butterfly farming, beekeeping, commercial tree nurseries, tour guiding and ecotourism which have contributed positively to community livelihoods.

Studies in ASFR (Matiku et al., 2013; Ndalilo et al., 2017) have reported that the community groups have recorded an increase in income generated from these activities over the past years following numerous capacity building initiatives spearheaded by various stakeholders supported by donors. For instance Jamii villas, a forest adjacent community ecotourism project located adjacent to ASFR recorded revenue of USD 31,689.50 in the year 2016 up from USD 1630.00 in 2014. Msitu Women Tree nursery group recorded USD 25,348.70 in 2016 up from USD 8905.00 in 2013, while Kipepeo project which deal with sale of butterfly pupae and honey generates an annual earning of USD 130,000.00.

Moreover the Arabuko Sokoke Ecotourism Scheme (ASSETS) project which offers education scholarships to forest adjacent students whose parents are actively involved in forest conservation has witnessed 583 students trained in secondary level of education and 12 students trained up to university level. This has provided opportunities for attachment of youth who acquire skills that ensure inclusive and equitable quality education that promote lifelong learning opportunity for all in line with SDG 4 . The above enterprises have immensely contributed to SDG 1 which seeks to end poverty in all its forms everywhere. The ethical question however is whether these projects have replaced the benefits derived from the forest, and could this result to more time being spent by members in these activities at the expense of forest conservation or would the benefits which are not necessary forest based alienate the benefiting households from the forest.

\subsection{Ethical Issues in Forest Governance}

The Kenya constitution 2010 obligates every citizen to take care of the environ- 
ment and appreciates that the environment is our heritage and the need to sustain it for the benefit of the future generations (RoK, 2010). The Forest Conservation and Management Act 2016, provides for improved governance and has been well expounded by creating and reforming organizations like KFS, Forest Conservation Committee (FCC) and CFAs (KFS, 2009; RoK, 2009b). The lower organizations have been provided clear formation and working guidelines (RoK, 2009a; RoK, 2009b; RoK, 2009c; KFS, 2015a; KFS, 2015b). This has ensured inclusivity in forest management including community, government (national and county), CBOs and development partners. Further in ASFR, the community have formed the Arabuko Sokoke Forest Adjacent Dwellers Association which is an umbrella of the three CFAs through which communities have partnered with KFS to manage ASFR so as to ease community mode of engaging with KFS and development partners, ensure conflict management and over-sighting.

The forest governance system in ASFR thus contributes to SDG 16 which promotes peaceful and inclusive societies for sustainable development, provide access to justice for all and build effective, accountable and inclusive institutions at all levels. The concept of sustainable development (UNDP, 2000) requires that development be done in a manner that meets the needs of the present without compromising the ability of future generations to meet their own needs (Horn, 2013). This definition brings up ethical issues as to what are these needs and what is the threshold of satisfaction? In the case of PFM in ASFR, the primary concern has been the exclusion of non-PFM households in accessing forest benefits where (Mbuvi \& Ayiemba, 2005) indicated that Non-PFM households earned less income as compared to PFM households. This scenario leaves out the majority of the community members from accessing these benefits. But should those not participating (therefore not spending their time in PFM activities like forest protection) be allowed to benefit equally like those participating?

Moreover, the community organizations representation may not be fair as the constitution of CFA committees and their representation has been hijacked by government or any other facilitating organization. The CFA get an introductory letter from KFS before they can be registered, KFS in most instances coordinates and supervises their elections. Further, key appointments to community-KFS committees have been legally prescribed where the chair and the secretary to the conservancy forest management level FCC is defined with the chair being directly remunerated by KFS. These entire scenarios bring forth serious ethical considerations. Additionally, the over-reliance by CFAs on external support to hold elections has further created room for hijacking of CFAs by the supporting organizations and facilitating selection of officials and not electing as expected of good governance practices.

The prescriptive nature of the process of communities participating in forest management requires technical knowledge, which has forced only the elite to be elected creating room for elite capture (KFS, 2009; KFS, 2915a; KFS, 2015b). This may be unethical as the real local people are being denied chance to exert 
effective control of their resources and livelihoods as noted by Minteer \& Miller (2010). Studies conducted by Mbuvi \& Ayiemba (2005) and Schreckenberg \& Luttrel (2009) in ASFR, the PFM pilot area showed that the poor would only be in the committees through deliberate project intervention and it has to be sustained through constant monitoring without which the poorest households would be excluded from CFA committees. The situation in ASFR is a pointer to inefficient systems of community involvement in forest management leading to questions about who makes which decision and how are the communities involved in the management of the resources, what rights do they have and how do they exercise them, and what opportunities exist for communities to engage the managers, policy makers and donors. At the local scale, inadequate representation of women in the CFA committees is yet another challenge. In the case of ASFADA, nearly $80 \%$ of the committee is represented by men (KFS Records). Women in ASFR are the majority in butterfly farming as well as fuelwood collection, the latter being the main product whose extraction is legally permitted in the forest. Even though, women lack the voice to give their input and attend awareness meetings on the regulations on fuelwood collection, which are often organized through CFAs.

\subsection{Legal Concerns and Implication on Sustainability}

Arabuko Sokoke forest reserve has a 25 year strategic plan, station based PFMP and has signed Forest Management Agreements (FMAs) with KFS hence providing an avenue for sustainable forest utilization through user groups that have formed a CFA (KFS, 2009) in each station. Forest user rights are accessed through PFMPs and formalised through FMAs. Moreover, the PFM guidelines provide for participation of youth, women and all stakeholders living in the forest area where PFM is being implemented, essentially contributing to SDG 5 on achieving gender equality and empowering all women and girls. The PFMPs (KFS, 2015b) are used as means for promoting restraint in the harvest and consumption of natural resources by prescribing what can be harvested and the quantities of each as noted by Robinson (2011). This ensures sustainable consumption and production patterns as elucidated in SDG 12. It also brings in negotiated positions which shift the ethical perceptions of different stakeholders. If this new positions are respected by all, an ethically acceptable balance is achieved. The issues of concern here would be how participatory and involving were the negotiations aimed at drafting PFMPs? Do they provide an opportunity for communities to have their prioritized demands and make compromises to satisfy those of others as Mutually Agreed Terms (MATS) as noted by Schroeder \& Pisupati (2010).

Additionally, the PFMPs provide for rehabilitation, tree nursery development and seedlings production as means for providing forest products and facilitating rehabilitation of degraded areas in the forest as defined in the forest management plans. The plans have clearly defined the research agenda for ASFR as a 
means for continuous improvement based on evidence, while the community nurseries are able to produce over one million seedlings supplementing the government supported ones with capacity to produce around 100,000 seedlings per year. This has ensured sustainable production of seedlings which also provides a source of income and means for livelihood capitals building avenue. The nursery groups are also accessing funds from other government funding streams to diversify their income sources. Additional ethical concerns have also arose with regard to FMA which formalizes what has been agreed in the PFMP. This leads to questions as to whether it is negotiated or imposed recognizing that it is a national template (KFS, 2015b) which each CFA is supposed to use, and whether its development process is robust enough to reflect the ethical spirit of The Forest Act and the Constitution of Kenya 2010 (RoK, 2010; RoK, 2016c) which provides for meaningful community participation of communities in forest management and equitable access and sharing of forest benefits (RoK, 2009a).

Further as indicated by Manning et al. (1999), there is an increasingly obvious deficit in representation between those suffering the consequences of forest loss and those perpetrating it, there is also a concern that the perpetrators are the users of the products and not necessarily the real poachers. The poacher is not guided by the feeling that "we do whatever we please to other animals" (Bekoff, 2002) but in most cases it is for their daily survival. This brings the question as to who should be punished by the law; the users or the perpetrators? With the question being who is the poacher? The hotelier using timber and poles poached from the forest or the person who cuts (poaches) to sell or both?

\subsection{Partnerships and Networks}

Arabuko Sokoke Forest is ranked second in Africa and fifty globally in biodiversity richness. The forest is estimated to hold about 50 species of globally rare plant species, three internationally endangered mammal species, six globally threatened bird species, many species of reptiles and invertebrates, and four endemic butterfly species (Collar \& Stuart, 1998; Forest Department, 2002; Lange, 2003; Oyugi et al., 2007). Its international significance in biodiversity conservation has enabled the forest to get support from several global, multilateral and national funding partners (Appendix I). The forest receives researchers and students from all over the globe for studies. With the increasing habitat destruction, the local communities are likely to be alienated and focus is likely to turn to the few intact forests in a bid to strengthen their protection. This would lead to the poor losing right of access to subsistence products like firewood for cooking, and funding opportunities to initiate alternative IGAs. Funding opportunities from both government and development partners for ASFR has been stable for the last 30 years (Appendix I). This contributes to SDG 17 which aims to strengthen the means of implementation and revitalize the global partnership for sustainable development.

Past studies (Mbuvi et al., 2015; Ndalilo et al., 2017) have shown that 
multi-stakeholder involvement in forest management coordinated by ASFMT has been weakened by lack of transparency and accountability resulting to poor forest management and minimal contribution to both forest conservation and local community livelihoods improvement despite sustained donor funding totalling to over US\$ 536 million. These findings have elicited ethical concerns as to whether the existing forest management approach is indeed effective, and who benefits from donor support in ASFR, and how do we invest the benefit?

\subsection{Building Fairness as a Basis for Enhancing Ethical Conduct in Forestry Management}

Many Foresters handle forest matters as technical matters and have very minimal engagement with the society and have been accused to care more about the forest than the community. The foresters seem to be guided by law and not fairness and ethically this is not right as it denies the communities the chance to benefit fairly with concerns more on future generations (intra-generational) rather than fair and equitable sharing of benefits (inter-generational) (Schroeder \& Pisupati, 2010). It will be important to ensure fairness to all including the forest so as to ensure no one level jeopardizes the opportunity of the other and the resource recognizing that sustainability is supreme.

In Kenya despite the rights of communities to a clean and healthy environment (RoK, 2016c) and clear provisions in the Forest Conservation and Management Act, 2016 to involve forest adjacent communities in forest management, most FAC do not see themselves as forest managers (RoK, 2016b). There is need for the forest managers to see the social contract and appreciate the ethical aspects by the officers considering themselves as "the local state" (Funder \& Marani, 2015) as was noted for environmental officer in Taita Tavetta County Kenya, when facilitating project with the communities living next to a river. They are required to appreciate their pivotal role in policy formulation, review and implementation, and facilitation of projects applied through a fair blend of formal and informal rules and governance arrangement produced through interplay of various stakeholders.

Fairness will start arousing ethical principles and make communities and other stakeholders ensure that justice prevails through continuous engagement with the agencies mandated to manage forest resources. Fairness does not mean equal (Schreckernberg et al., 2016) but situations like the poor or the rich getting more than the other is fair as long as it is agreed upon by society and done openly and through a negotiated process where all are involved and agree and abide by the regulations. In Loita Forest, the society donates and grazes livestock for the children of the poor who do not participate in forest management (Mbuvi \& Musyoki, 2013). Though practically wrong, from a social and ethical perspective it is right as they are investing in the future of that household, and it is socially agreed.

The forest management agreements signed between the communities are negotiated and involves several stakeholders to moderate and ensure that they are 
suitable for the local conditions and that there is no serious harm to all the parties and that ultimately the resource is managed for public good before signing.

\section{Conclusion and Recommendation}

Arabuko Sokoke forest reserve and other forests being managed through partnerships have witnessed tremendous improvement in conservation efforts, organizational transformation exhibited by multi-stakeholder partnerships, diversified household income sources, improved governance exemplified by community and other stakeholder participation in forest management through several forest based committees and partnerships. The forest has very strong oversighting by the local, national and global citizenry who have also sustainably supported its conservation, governance and community livelihood improvement activities. This has facilitated the management to adapt to the changing socio-economic scenarios which has brought in ethical consideration by demanding fairness and equity targeting inclusion of all especially the poor and other disadvantaged members of the society so that it can ensure sustained participation of the communities. This also obligated the global citizen to provide alternatives to direct forest utilization for the common large societal good. The best approach could be adaptive as it allows plurality of goals and the incorporation of a range of different values in forest management.

\section{Acknowledgements}

The authors are very grateful to the individuals who participated in the survey especially the focus group discussion participants and the Key informants for the valuable contributions. We acknowledge the founders of the different research projects that provided the information that was used in the review to develop this journal paper and lastly the anonymous reviewers.

\section{Author Contributions}

The key contributions of the authors were: Mũsingo T. E. Mbuvi: conceived the paper and developed the first draft, developing the checklist to guide focus group discussion and key informant interviews, revising the drafts and ensuring the final paper quality as the corresponding author. Leila A. Ndalilo: paper writing, literature review and coordinating and undertaking focus group discussion, Key informant interview and paper editing. Aden Hussein: literature review and undertaking key informant interviews, review of livelihood activities and writing up the paper.

\section{Conflicts of Interest}

The authors declare no conflict of interest. The sponsors of the various sources of the information used had no role in the design of the review; in the collection, analyses, or interpretation of data; in the writing of the manuscript, and in the 
decision to publish the results.

\section{References}

Bekoff, M. (2002). The Importance of Ethics in Conservation Biology: Let's Be Ethicists Not Ostriches. Endangered Species Update, 19, 23-26.

Collar, N. J., \& Stuart, S. N. (1998). Key Forests for Threatened Birds in Africa. Monograph 3. Cambridge: International Council for Bird Preservation.

Convention on Biological Diversity (CBD) (2010). United Nations Environment Programme.

FAO (1999). State of the World's Forests (154 p). Rome: FAO.

Forest Department (2002). Arabuko Sokoke Strategic Forest Management Plan 2002-2027 (66 p.). UK: Birdlife International.

Funder, M., \& Marani, M. (2015). Local Bureaucrats as Bricoleurs. The Everyday Implementation Practices of County Environment Officers in Rural Kenya. International Journal of the Commons, 9, 87-106.

Gibson, C., McKean, M. A., \& Ostrom, E. (2000). People and Forests: Communities, Institutions, and Governance. Cambridge: MIT Press.

Gore, M. L., Nelson, M. P., Vucetich, J. A., Smith, A. M., \& Clark, M. A. (2011). Exploring The Ethical Basis for Conservation Policy: The Case of Inbred Wolves on Isle Royale, USA Conservation Letters, 4, 394-401.

Guha, R. (1989). Unquiet Woods: Ecological Change and Peasant Resistance in the Himalaya. Delhi: Oxford University Press.

Horn, V. (2013). Ethical \& Sustainability. Texas: Centre for Human \& Nature.

Kant, I. (1968). Critique Is the Critique of Judgement. New York: Harper.

Kenya Forest Service (2015a). Participatory Forest Management Guidelines. Nairobi: KFS.

Kenya Forest Service (2015b). Manual on Preparation of a Participatory Forest Management Plan (PFMP). Nairobi: KFS.

Kenya Forest Service KFS (2009). Manual on Forming and Registering Community Forest Associations (CFAs). Nairobi: Kenya Forest Service and Kenya Forest Working Group.

Lange, C. N. (2003). Environmental Factors Influencing Land Snail Diversity Patterns in Arabuko-Sokoke Forest, Kenya. African Journal of Ecology, 41, 352-355.

https://doi.org/10.1111/j.1365-2028.2003.00482.x

Logie, J. P. W., \& Jones, G. A. (1968). Land Use Planning for Forestry in Kenya. East African Agricultural and Forestry Journal, 1-4.

Macqueen, D. J. (2004). Forest Ethics: The Role of Ethical Dialogue in the Fate of the Forests. Comparing and Contrasting the International Forest Policy Dialogue with the Earth Charter Initiative. In International Conference on Global Ethics, Development, Environment and the Earth Charter (p. 20). Aberdeen: University of Aberdeen.

Manning, R., Valliere, W., \& Minteer, B. (1999). Values, Ethics and Attitudes toward National Forest Management. An Empirical Study. Burlington, VT: University of Vermont.

Matiku, P., Caleb, M., \& Callistus, O. (2013). The Impact of Participatory Forest Management on Local Community Livelihoods in the Arabuko Sakoke Forest, Kenya. Conservation \& Society, 11, 112-129. https://doi.org/10.4103/0972-4923.115724 
Mbuvi, M. T. E., \& Ayiemba, W. O. (2005). Sustained Natural Resources Management and Community Livelihoods Improvement through Partnerships: The Case of Arabuko Sokoke Forest Kenya. In 1st International Congress on Successful Cases in Sustainable Development in the Tropics (p. 548). Veracruzana: Universidad.

Mbuvi, M. T. E., \& Musyoki, J. K. (2013). Impacts of Participatory Forest Management on Community Livelihoods: A Case Study of Dida Community Adjacent to Arabuko-Sokoke Forest in Kilifi County, Kenya. World Journal of Agricultural Sciences, 1, 44-55.

Mbuvi, M. T. E., Ayiemba, W. O., \& Wambua, S. (2007). Costs and Benefits of the Arabuko-Sokoke Forest Reserve: Local, National and Global Level Perspectives.

Mbuvi, M. T. E., Musyoki, J. K., \& Ongugo, P. O. (2015). Equity Mechanisms in Traditional Forest Management Systems: A Case Study of Loita Forest in Kenya. Journal of Sustainable Forestry, 34, 380-405. https://doi.org/10.1080/10549811.2015.1010092

Ministry of Environment, Water and Natural Resources (2015). Draft National Forest Policy 2015. Nairobi: Government Printers.

Minteer, B. A., \& Miller, T. R. (2010). The New Conservation Debate: Ethical Foundations, Strategic Trade-Offs and Policy Opportunities. Biological Conservation, 114, 945-947.

Muriithi, S., \& Kenyon, W. (2002). Conservation and Biodiversity in Arabuko-Sokoke Forest, Kenya. Biodiversity Conservation, 11, 1437-1450.

https://doi.org/10.1023/A:1016234224819

Ndalilo, L., Mbuvi, M. T. E., \& Luvanda, A. (2017). Utilization and Governance of Arabuko Sokoke Forest. In Biodiversity Status of Arabuko Sokoke Forest (pp. 47-59). Nairobi: Kenya Forestry Research Institute.

Oyugi, J. O., Brown, J. S., \& Whelan, C. J. (2007). Effects of Human Disturbance on Composition and Structure of Brachystegia Woodland in Arabuko-Sokoke Forest, Kenya. African Journal of Ecology, 46, 374-383. https://doi.org/10.1111/j.1365-2028.2007.00850.x

Republic of Kenya RoK (2009a). Forests (Harvesting) Rules 2009. Nairobi: Government Printer.

Republic of Kenya RoK (2009b). Forest (Charcoal) Rules 2009. Nairobi: Government Printer.

Republic of Kenya RoK (2009c). Forests (Participation in Sustainable Forest Management) Rules 2009. Nairobi: Government Printer.

Republic of Kenya RoK (2010). The Constitution of Kenya 2010. Nairobi: Government Printer.

Republic of Kenya RoK (2016a). The Forest Conservation and Management Act (2016).

Republic of Kenya RoK (2016b). National Forest Programme (2016-2030), Ministry of Environment and Natural Resources. Nairobi: Government Printer.

Republic of Kenya RoK (2016c). The Forests (Fees and Charges) Regulations 2016, Special Issue 1469. Kenya Gazette Supplement No. 16 of 26th February, 2016. Legislative Supplement No. 12. Legal Notice No. 21. Nairobi: Government Printer.

Robinson, J. G. (2011). Ethical Pluralism, Pragmatism, and Sustainability in Conservation Practice: Biological Conservation (pp. 1-8).

https://doi.org/10.1016/j.biocon.2010.04.017

Schreckenberg, K., \& Luttrell, C. (2009). Participatory Forest Management: A Route to Poverty Reduction? The International Forestry Review, 11, 221-238.

https://doi.org/10.1505/ifor.11.2.221 
Schreckernberg, K., Franks, P., Martin, A., \& Lang, B. (2016). Unpacking Equity for Protected Area Conservation. Parks, 22, 12-26.

Schroeder, D., \& Pisupati, B. (2010). Ethics, Justice and the Convention of Biological Diversity.

UNDP (2000). Sustainable Development Goals.

Wass, P. (1995). Kenya's Indigenous Forests. Status, Management and Conservation. Cambridge and Gland: IUCN. 


\section{Appendix I: Trend Analysis of Jointly Implemented Projects} in ASFR (1990-2017)

\section{Kenya Indigenous Forest Conservation Project (KIFCON) 1 (1990-1993)}

- It demonstrated that there are formal and informal benefits of the forest to the community

- It demonstrated that informal (illegal) benefits from ASFR were higher than the legalized benefits

- Started the initial attempts for community participation in forest management

- It facilitated the initiation of the process of KWS participation in joint management of ASFR through a Memorandum of Understanding (MOU)

- The biggest challenge was how to legalize, diversify and spread the benefits Kipepeo Project (1993 to date)

- It demonstrated that communities could get higher returns from non-timber forest products such as butterflies

- It demonstrated that the attitude of the community towards forest conservation is directly related to the benefits they draw from it

- This project started ("opened eyes") the first forest based direct non-consumptive benefits

- By 2000 it started facilitating sale of honey produced by ASFR FAC with an equipped marketing centre where honey is processed and packaged

- The project has not received funding since 2006

Promotion of Sustainable Forest Management (PSFM) 3 (1993-1998)

- Emphasized on sustainable management of natural forests

- It initiated on-farm forestry

- Conducted Participatory Rural Appraisal (PRAs) focused to initiating community involvement in forestry management

Arabuko-Sokoke Forest Management and Conservation Project (ASFMCP)

4 (1997-2001)

- Build capacity of Government officers and community to support forest management paradigm shift

- Initiated Participatory Forest Management (PFM) and integrated rural development

- Expanded existing forestry related Income Generating Activities (IGAs) and initiated new ones like beekeeping, community patrolling

- Further developed the ASFMT and community partnerships and structures

- Government increased funding towards multiple stakeholder management in ASFR

Arabuko Sokoke Forest Community Conservation Initiatives 5 (2003-2005)

- Project developed and implemented equally by Government and Community

- Initiated joint human-wildlife conflict deterrent through construction of electric fence in ASF and did the initial $20 \mathrm{~km}$ solar fence

- Initiated joint community and Government officers cross-site visits 
- Consolidated existing IGAs like Eco-Tourism, Butterfly farming and Bee keeping

- Initiated new IGAs like Mushroom farming

- Enhanced equity in partnership between ASFMT and FAC

Enhanced sustainability of Arabuko-Sokoke forest through Improved Natural Resources Management by and for Stakeholders 6 (2003-2006)

- Consolidating existing IGAs like Eco-Tourism, Butterfly farming and Bee keeping

- Facilitating the completion of the PFM piloting, scaling up and starting a monitoring system

- Building CBOs capacity in organization and advocacy

- Initiated Aloe vera farming as a new IGA

- Expanded PFM to cover two more sites in ASF

Developing Incentives for Community Participation in Forest Conservation through the use of Commercial Insects in Kenya 7 (2004-2008)

- Awareness on Participatory Forest Management.

- Beekeeping and sericulture as Income Generating Activities

- Expanded PFM to cover two more sites in ASFR

- Capacity building of communities

People and Sustainable Development: Investing in Education, and Social and Economic Empowerment to conserve globally threatened biodiversity in Arabuko-Sokoke Forest, Kenya 8 (2004-2008)

- Improving household livelihood so that children live a better life through better farming methods and use of NTFPs

- Provision of water

- Beekeeping

- Initiated Farm Forestry Field School for improving farming Kenya Coastal Development Project 9 (2010-2017)

- Biodiversity assessment in ASF

- Support to community nursery groups

- Establishment of commercial woodlots

- Rehabilitation of degraded forest ecosystems

- Establishment and maintenance of seed sources Smallholder Innovation for Resilience Project 10 (2012-2017)

- Improving the adaptive capacity of Coastal communities against the impacts of climate change

- Sustainable utilization of forest products for Nature based Enterprises development

- Capacity building of community groups in Nature based enterprises

- Preservation of cultural heritage and conservation of agrobiodiversity Arabuko Sokoke Landscape Project 11 (2012-2015)

- Improving household livelihood

- Awareness on PFM

- Capacity building of local communities 
Strengthening Community Capacity to adapt to Climate Change 12 (2014-2015)

- Planting of drought resilient crops

- Establishment of tree nurseries

- Poultry keeping

- Capacity building of Farm Forestry Field School (FFFS)

Capacity building of Forest Adjacent Communities, Kenya 13 (2015-2017)

- Capacity building of local communities

- Enhancing the effectiveness of Community forest associations 